\title{
KEBUTUHAN TENAGA KESEHATAN MASYARAKAT DI PUSKESMAS PADA ERA COVID19
}

\section{PENDAHULUAN}

Pandemi COVID-19 merupakan sebuah krisis global dan bencana non alam berdampak di seluruh sektor kehidupan, bukan hanya mengancam kesehatan masyarakat secara fisik, namun juga dapat memberikan dampak pada kondisi kesehatan jiwa dan psikososial setiap orang. Hal ini sangat mempengaruhi seluruh aktivitas masyarakat, demikian juga dalam dunia pendidikan yang berdampak langsung yaitu dengan diliburkan dari seluruh berbagai kegiatan di seluruh tanah air dan dialihkan dari pembelajaran tatap muka menjadi E-learning (daring), adanya kebijakan stay at home, Work From home (WFH), dan tentunya yang paling berdampak adalah mereka-mereka yang terpapar COVID-19, termasuk yang merawatnya. Kondisi kesehatan masyarakat terkait penularan virus COVID-19 dibagi menjadi orang tanpa gejala, orang dengan pemantauan, pasien dengan pengawasan, dan orang yang menderita COVID-19 atau

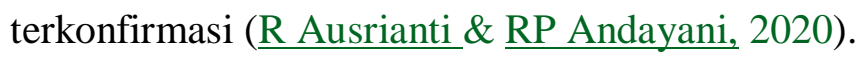

Puskesmas merupakan garda terdepan dalam memutus mata rantai penularan Covid19 karena berada di setiap kecamatan dan memiliki konsep wilayah. Dalam kondisi pandemi Covid-19 ini, puskesmas perlu melakukan berbagai upaya dalam penanganan pencegahan dan pembatasan penularan infeksi. Pemutusan mata rantai Covid-19 saat ini hal tersebut menjadi prioritas kerja bidang kesehatan. Namun puskesmas tidak dapat meninggalkan pelayanan lain yang menjadi fungsi puskesmas yaitu melaksanakan upaya kesehatan masyarakat (UKM) dan upaya kesehatan perorangan (UKP) tingkat pertama. Hal ini telah ditetapkan dalam Peraturan Menteri Kesehatan (Permenkes) Nomor 43 Tahun 2019 tentang Pusat Kesehatan Masyarakat (Kemenkes RI, 2020) dalam (FD Umpung et al, 2020).

Keberhasilan puskesmas dalam melakukan tugas dan fungsinya sangat dipengaruhi oleh penataan dan pengelolaan sumber daya manusia (SDM) untuk melaksanakan kegiatan pokok puskesmas. SDM yang seimbang antara upaya kuratif dan upaya 
promotif dan preventif. SDM di layanan kesehatan (tenaga kesehatan dan nonkesehatan)merupakan hal yang paling utama dalam pencapaian keberhasilan suatu tujuan dari pembangunan kesehatan. Meningkatnya suatu pelayanan kesehatan tergantung pada kemampuan SDM dalam menjalankan aktivitasnya. Sumber Daya Manusia Kesehatan (SDMK) termasuk salah satu subsistem yang mempunyai peranan penting dalam meningkatkan derajat kesehatan masyarakat melalui berbagai upaya dan pelayanan kesehatan yang dilakukan. Persoalan SDMK harus diberi perhatian lebih dan dikelola secara optimal serta berkelanjutan dalam hal memenuhi hak-haknya. Hal itu dilakukan agar bisa mendapatkan SDM yang mampu, terampil, berkualitas, bekerja giat dan berkeinginan untuk mencapai produktivitas kerja yang tinggi serta dapat menghadapi berbagai permasalahan dan memecahkannya secara cerdas, baik dan benar (Kemenkes RI, 2020; Kemenkes RI, 2015) dalam (FD Umpung et al, 2020).

SDM merupakan penghasil pendapatan pada fasilitas pelayanan kesehatan. Kebutuhan SDM dihitung berdasarkan kebutuhan unit pelayanan. Kekurangan pemenuhan kebutuhan SDM memberikan efek beban kerja yang tinggi kepada tenaga kerja dan berakibat menurunkan kepuasan dalam bakerja, meningkatkan kejadian burnout, meningkatkan keinginan pindah kerja, menurunkan kualitas keselamatan pasien sehingga akan menurunkan kualitas pelayanan pada

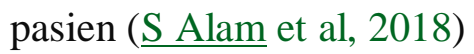

\section{Peranan tenaga Kesehatan Masyarakat di PUSKESMAS pada era COVID-19 yaitu :}

1. Penyuluhan mengenai Disiplin Protokol Kesehatan Covid-19

Kegiatan penyuluhan yang dilaksanakan mengacu kepada standar disiplin protokol kesehatan yang telah ditetapkan oleh Kementerian Kesehatan RI. Menurut Kemenkes (2020), cara pencegahan penularan Covid-19 terhadap individu meliputi sebagai berikut :

1. Menerapkan kebiasaan cuci tangan pakai sabun dan air mengalir selama 40 - 60 detik atau menggunakan cairan antiseptik berbasis alkohol (handsanitizer) minimal $20-30$ detik.

2. Membiasakan penggunaan alat pelindung diri berupa masker yang menutupi hidung dan mulut jika harus keluar rumah atau berinteraksi dengan orang lain yang tidak diketahui status kesehatannya. 
3. Menerapkan kebiasaan jarak minimal 1 meter dengan orang lain untuk menghindari terkena droplet dari orang yang yang batuk atau bersin.

4. Membatasi diri terhadap interaksi atau kontak dengan orang lain yang tidak diketahui status kesehatannya.

5. Saat tiba di rumah setelah bepergian, segera mandi dan berganti pakaian sebelum kontak dengan anggota keluarga di rumah.

6. Meningkatkan daya tahan tubuh dengan menerapkan pola hidup bersih dan sehat (PHBS).

7. Mengelola penyakit penyerta/komorbid agar tetap terkontrol.

8. Mengelola kesehatan jiwa dan psikososial.

9. Menerapkan etika batuk dan bersin.

10. Menerapkan adaptasi kebiasaan baru dengan melaksanakan protokol kesehatan dalam setiap aktivitas.

\section{(L Farokhah et al, 2020).}

2. Posyandu Balita

Posyandu merupakan salah satu bentuk Upaya Kesehatan Bersumberdaya Masyarakat (UKBM) yang dikelola dari, oleh, untuk, dan bersama masyarakat, guna memberdayakan masyarakat dan memberikan kemudahan kepada masyarakat dalam memperoleh pelayanan kesehatan dasar bagi ibu, bayi dan anak balita. Kegiatan posyandu ini terdiri dari kegiatan utama dan kegiatan pengembangan/pilihan. Kegitan utama mencangkup: kesehatan ibu dan anak, keluarga berencana, imunisasi, gizi, pencegahan dan penanggulangan diare. Posyandu balita pada dasarnya penting untuk memantau kesehatan anak berupa asupan nutrisi, pertumbuhan dan perkembangan anak, pemberian vitamin A, pemberian obat cacing dan imunisasi. Walaupun hal tersebut dapat ditunda sementara dengan alas an pandemic COVID19, tapi dapat juga menyebabkan hal yang serius seperti kurangnya pemantauan perkembangan anak sehingga dapat menyebabkan terjadinya gangguan perkembangan motorik, bahasa dan perilaku, maka dari itu tidak ada kata berhenti untuk memantau walaupun secara mandiri (A Setyawan et al, 2020 ).

3. Promosi Kesehatan

Promosi Kesehatan memiliki tujuan memberikan informasi bagi masyarakat terkait segala hal yang bertujuan pada peningkatan kualitas kesehatan; baik itu kesehatan individu maupun masyarakat. Fungsi promosi kesehatan sebagai penyaring informasi langsung dari 
tingkat masyarakat. Promosi kesehatan adalah kenyataan bahwa upaya-upaya "health education" atau pendidikan (penyuluhan) kesehatan tidak dengan serta merta atau tidak dengan mudah membuat individu ataupun masyarakat berperilaku yang menguntungkan kesehatan, karena pendidikan kesehatan bertujuan untuk menghasilkan perilaku yang menguntungkan kesehatan, dan perilaku itu bersifat sukarela (A Setyawan et al, 2020 ). 


\section{DAFTAR PUSTAKA}

Ausrianti, Rizka, and Rifka Putri Andayani. "PROMOSI KESEHATAN JIWA MASYARAKAT MENGHADAPI ERA NEW NORMAL." Jurnal Abdimas Saintika 2.2 (2020): 97-101. http://www.jurnal.syedzasaintika.ac.id/index.php/abdimas/article/view/840

Umpung, Festy Debora, Junita Maya Pertiwi, and Grace Ester Caroline Korompis. "Faktor-Faktor yang Mempengaruhi Motivasi Kerja Tenaga Kesehatan di Puskesmas Kabupaten Minahasa Tenggara Pada Masa Pandemi Covid 19." Indonesian Journal of Public Health and Community Medicine 1.4 (2020): 18-27. https://ejournal.unsrat.ac.id/index.php/ijphcm/article/view/31024

Farokhah, Laely, Yusfi Ubaidillah, and Rury Arista Yulianti. "Penyuluhan Disiplin Protokol Kesehatan Covid-19 Di Kelurahan Gandul Kecamatan Cinere Kota Depok." Prosiding Seminar Nasional Pengabdian Masyarakat LPPM UMJ. Vol. 1. No. 1.2020. https://jurnal.umj.ac.id/index.php/semnaskat/article/view/7970

Alam, Syamsul, Sitti Raodhah, and Surahmawati Surahmawati. "Analisis Kebutuhan Tenaga Kesehatan (Paramedis) Berdasarkan Beban Kerja Dengan Menggunakan Metode Workload Indicator Staffing Needs (WISN) di Poliklinik Ass-Syifah UIN Alauddin Makassar." Al-sihah: The Public Health Science Journal 10.2 (2018).

Setyawan, Agus, and Fairuz Azmila Purnomo. "Sosialisasi Peningkatan Pengetahuan Ibu Hamil dan Balita dalam Pemantauan Secara Mandiri Pada Era Pandemik COVID-19 di Kelurahan Ngesrep Semarang." Seminar Nasional Pengabdian Kepada Masyarakat UNDIP 2020. Vol. 1. No. 1. 2020.http://www.proceedings.undip.ac.id/index.php/semnasppm2019/article/viewFile/395/250 